\title{
Use Behavior of E-Money: Empirical Analysis Using The UTAUT Model
}

\author{
Rahmiati $^{1 *}$, Perengki Susanto ${ }^{2}$ \\ 1, 2 Universitas Negeri Padang, Padang, Indonesia \\ *Corresponding Author: Email: rahmiati@fe.unp.ac.id
}

\begin{abstract}
In recent years, the use of e-money in many countries as a non-cash payment mechanism has increased. To evaluate the determinant factors of e-money adoption, a variety of studies have been performed. The goal of this research is to examine e-money usage behavior using the model of UTAUT (Unified Theory of Acceptance and Use of Technology). The conduct of usage shows how much e-money is used as a payment form. 193 e-money consumers in West Sumatra who were taken by online surveys were a sample of this analysis. The data was evaluated using Structural Equation Modeling-Partial Least Square (SEM-PLS). The findings found that three UTAUT variables have been identified that have a major impact on behavioral intentions, namely effort expectations, social influences and facilitating conditions. Interestingly, the UTAUT variable has no direct effect on the use behavior of e-money. This finding indicates that effort expectations, social effects and facilitating conditions can only impact the desire of the consumer to use e-money and have no effect on the strength of the use of e-money. This study's result may lead to other researchers who want to examine the influence of the use of technology on individual outcomes.
\end{abstract}

Keywords: E-money, UTAUT model, use behavior, behavior intention, Indonesia.

\section{INTRODUCTION}

The advancement of electronic payment technologies has contributed to the introduction of new payment system developments that are intended to include ease, reliability, performance and accessibility of transaction behavior [1]. A payment mechanism is known as electronic money (e-money) that is able to handle these issues. It is considered that the use of e-money as a micro payment instrument is the most appropriate and capable of reacting to the need for an easy and relatively cheap payment mechanism.

Regulation No 20/6/PBI/2018 of Bank Indonesia Article 3(2) explains that electronic money (e-money) is stored electronically in a media server or chip that can be exchanged for payment transactions and/or transfers of fund. It can be said, on the basis of this Bank Indonesia rule, that e-money has the same purpose as cash and is not both a deposit and a debit card. For developers or customers, e-money has certain benefits. Consumers should not need to carry cash in vast numbers when making purchases in order to improve protection and flexibility in shopping. E-money also allows buyers to reduce the chance of failure, and minor adjustments in the cash of the vendor are not supposed to be available. Besides that, the rising use of electronic money in
Indonesia has attracted the ease of filling in electronic money balances.

The use of e-money promotes the growth of ecommerce purchases. The challenge for e-commerce players is to build an electronic payment mechanism that is secure and convenient. E-commerce customers still need offline payments for e-commerce transactions and 26 percent still rely on automated teller machine (ATM) transfer payments [2]. E-money usage can significantly support the deployment of e-commerce in Indonesia. Data from Bank Indonesia notes that the average growth rate of E-money transaction volume in the last five years is 89 percent. Highest growth in 2018 is 210 percent. This demonstrates the high interest of the public in using e-money as a non-cash payment mechanism, especially in Indonesia's urban areas.

E-money has led to numerous studies conducted by academics in Indonesia. For instance, Research performed by Rahmiati et al. [3] to analyze the strength of e-money use using the TAM model and trust variable. The study results indicate that the relative ease of usage and trust in the intensity of e-money use have a substantial impact. Research conducted by Khatimah et al. [4] has shown that the use of e-money is affected by social influence and habit. Deny [5] explores the variables affecting Go-Pay adoption and finds four 
dominant variables influencing the intensity of use, namely social influence, hedonic motivation, price value, and habit. However, in their study, Susanto et al. [6] who used the UTAUT model found different outcomes from previous studies, performance expectation and social effects did not influence the use of e-money. Other empirical research on e-money, such as Miliani et al. [7] and Angelina [8], have also found contradictory findings.

UTAUT is a model suggested by Venkatesh et al. [9], which is often referred to describes user behavior towards technology. The UTAUT model explains that behavioral intention and use behavior is influenced by performance expectancy, effort expectancy, social influence and facilitating conditions. These four factors are moderated by gender, age and experience. In order to understand the actions of information system users, Handayani and Sudiyana [10] used the UTAUT model. Isaac et al. [11] used the UTAUT model to explain the behavior of Internet usage. Gunawan et al. [12] used UTAUT to test micro, small and medium-sized enterprises' readiness to use e-money. E-commerce as group of digital actors can build an electronic payment system with a high level of usage in society by knowing the behavior of the use of e-money.

\section{LITERATURE REVIEW}

\subsection{Definition of Electronic Money (E-Money)}

Micro-scale payment instruments have recently moved from using cash to digital payments in various transactions in Indonesia. In several countries, the use of e-money as an alternative to the cashless payment method shows considerable potential to reduce cash growth. On the relation to Article 3, paragraph 2, of Regulation No 20/6/PBI/2018 of Indonesian Bank Indonesia, it is clarified that electronic money as a payment instrument shall comply with the elements. As defined in banking legislation, the value of electronic money handled by the issuer is not a deposit.

In making a deposit or charge, the contrast between electronic money and a debit or credit card issued by a commercial bank can be seen. The card reader needs to be online with the bank on a debit or credit card. If not, so there is no transaction that can be made. Meanwhile, it is not important to link e-money to the network, only swiping it on the chip reader, the balance on the card will decrease instantly based on the purchase made. In addition, e-money transfers with servers can also be carried out using a mobile phone device, but the balance can be lowered immediately based on the number of transactions. In other words, without the need to be attached to a bank, transfers of e-money can be made anywhere. Compared to credit or debit cards, this is the benefit of e-money.

\subsection{UTAUT Mode}

The presence of information technology has changed the way companies work. Information technology can improve company performance as long as it can be accepted and used in advance by users. How technology is accepted and used by users has been tested by various theories. Venkatesh, et al. [9] tested 8 previous models of framework consumer acceptance of technology as follows: "(1) theory of reasoned action or TRA); (2) technology acceptance model or TAM); (3) motivational model or MM); 4) theory of planned behavior or TPB; 5) a model combining the technology acceptance model and the theory of planned behavior orTAM+TPB); 6) model of PC utilization atau MPCU; 7) innovation diffusion theory or IDT), and; 8) social cognitive theory or SCT)".

To derive a new integrated combined model, Venkatesh uses these 8 theories. "The Unified Theory of Acceptance and Use of Technology", or UTAUT, is known as this model. Some of the limitations of evaluating the previous models were clarified by Venkatesh et al. [9]. Second, basic and individualoriented technology appears to be the technology under review, not advanced technology with complicated issues. Third, when the measurement is carried out directly after the decision to accept or reject it is not when this technology was first introduced. Fourth, the nature of measuring through several stages of experience using the same technology. Finally, to become generalized, the study background should use volunteers and mandatory outcomes.

\subsection{Determinant Factors of Use Behavior}

This research applies UTAUT model which are consist of four major factors that are direct sources of behavioural intent or use. They are performance expectancy, social influence, effort expectancy, and facilitating condition. Performance expectancy is welldefined as the degree to which an individual believes that using the system will help to increase job performance [9]. This framework is equivalent to the supposed relevance of Davis et al. in TAM [13]. The key factor influencing the use behavior of a given technology is performance expectancy [13]. Therefore, performance expectancy is predicted to have a positive effect on behavioral intent and behavioral use.

This construct is similar with perceived usefulness in TAM by Davis et al. [13]. Performance expectancy is the main factor that determines use behavior of a certain technology [14]. Hence, it is expected that performance expectancy has a positive influence on behavioral intention and use behavior. Prior studies have shown that performance expectations or perceived usefulness, such as $[11,11,13,14,15,16]$, play a dominant role in the context of the system.

Effort expectancy is described as the level of ease associated with the use of the system [9]. With regards to e-money, it describes the level of effort that must be spent in order to interact and use electronic payment systems easily. The easier a system is to use, the greater the intention of users to use the system [10]. This construct is pertaining to perceived ease of use in Davis et al. [13].

Social influence applies to the belief of a person that significant people think what can use the new method [9]. Relation to this study, e-money as new payment system is changing the consumer behavior especially external factors such as social influence. Users can be motivated to adopt the same technology or method, such as influence by families, coworkers or particular groups, through the influence of others who are considered significant. The most important, how friends or family 
members value the use of a technology impacts human behavior [17].

Facilitating condition in a UTAUT framework is a supporting state that is known to have a direct effect on the adoption of technology [17]. This is described as the extent to which a person believes that there is an organizational and technological infrastructure to facilitate the use of system [9]. It is assumed that the enabling factors will have a beneficial impact on the actions of the use of e-money. It is assumed that the enabling factors will have a beneficial impact. The provision of e-money tools, assistance and information also allows people to use e-money.

The following conclusions were made out of the scientific hypothesis:

H1: Performance expectancy significantly increases behavioral intention.

$\mathrm{H} 2$ : Performance expectancy significantly increases use behavior.

H3: Effort expectancy significantly increases behavioral intention.

H4: Effort expectancy significantly increases use behavior.

H5: Social influence significantly increases behavioral intention.

H6: Social influence significantly increases use behavior.

H7: Facilitating condition significantly increases behavioral intention.

H8: Facilitating condition significantly increases use behavior.

H9: Behavioral intention significantly increases use behavior.

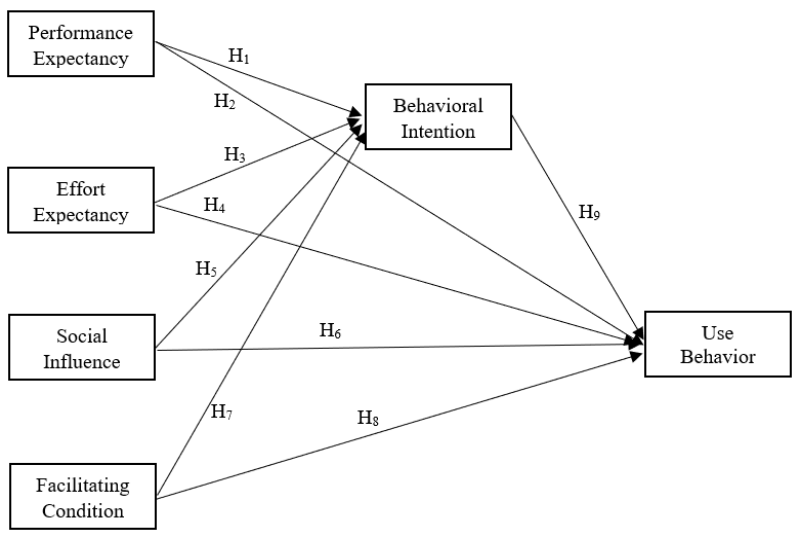

Figure 1 Research Model

\section{METHOD}

The research was carried out in West Sumatra Province-Indonesia. Respondents who are conscious of e-money in this study. The cumulative sample was 193 respondents. Data collected was using an online survey. A survey instrument was developed to validate the model seen in Fig 1, based on previously existing literature. From Venkatesh et al. [9], the items for Acceptance and use of technology constructs were selected. The unit research focused on the user and the responses were calculated at an interval level ranging from "strongly disagree" to "strongly agree" using a 5-point Likert - type scale.

To validate the model, variance-based Structural Equation Modeling (SEM) was used. Partial least squares (SEM-PLS) were the approach used to approximate the SEM and the Smart PLS 3.0 software was used to test the proposed research model. The analysis, calculation and structural model is extended to two steps of assessment.

The evaluation of the calculation model in the first step checked the reliability of the construct's internal accuracy by means of composite reliability and Cronbach 's alpha reliability, which must have values greater than $0.7[18]$. Convergent validity, with a minimum value of 0.5 , was then measured by means of average variance extract (AVE).

The first step, the examination of the measurement model checked the precision of the construct's internal consistency by composite reliability and Cronbach 's alpha, which must have values greater than 0.7 [18]. Then, average variance extract (AVE) was used to evaluate convergent validity, with a minimum value of 0.5 . Finally, to verify that the square roots of the AVE score are greater than the correlation between the constructs, discriminant validity was tested.

In the second point, the structural model evaluation began by acquiring the determination coefficient (R2). The values obtained in this study by measuring the direction of the relationship among variables. Then, for evaluating the hypotheses, direction coefficient estimates are used.

\section{RESULT \\ 4.1. Measurement Model}

Composite reliability assessment determines internal accuracy and average variance extracted (AVE) to test convergent validity. The research model used reflective measurement models. Discriminant validity that is tested based on cross loading is often used in the examination of reflective measurement as suggested by prior study. 


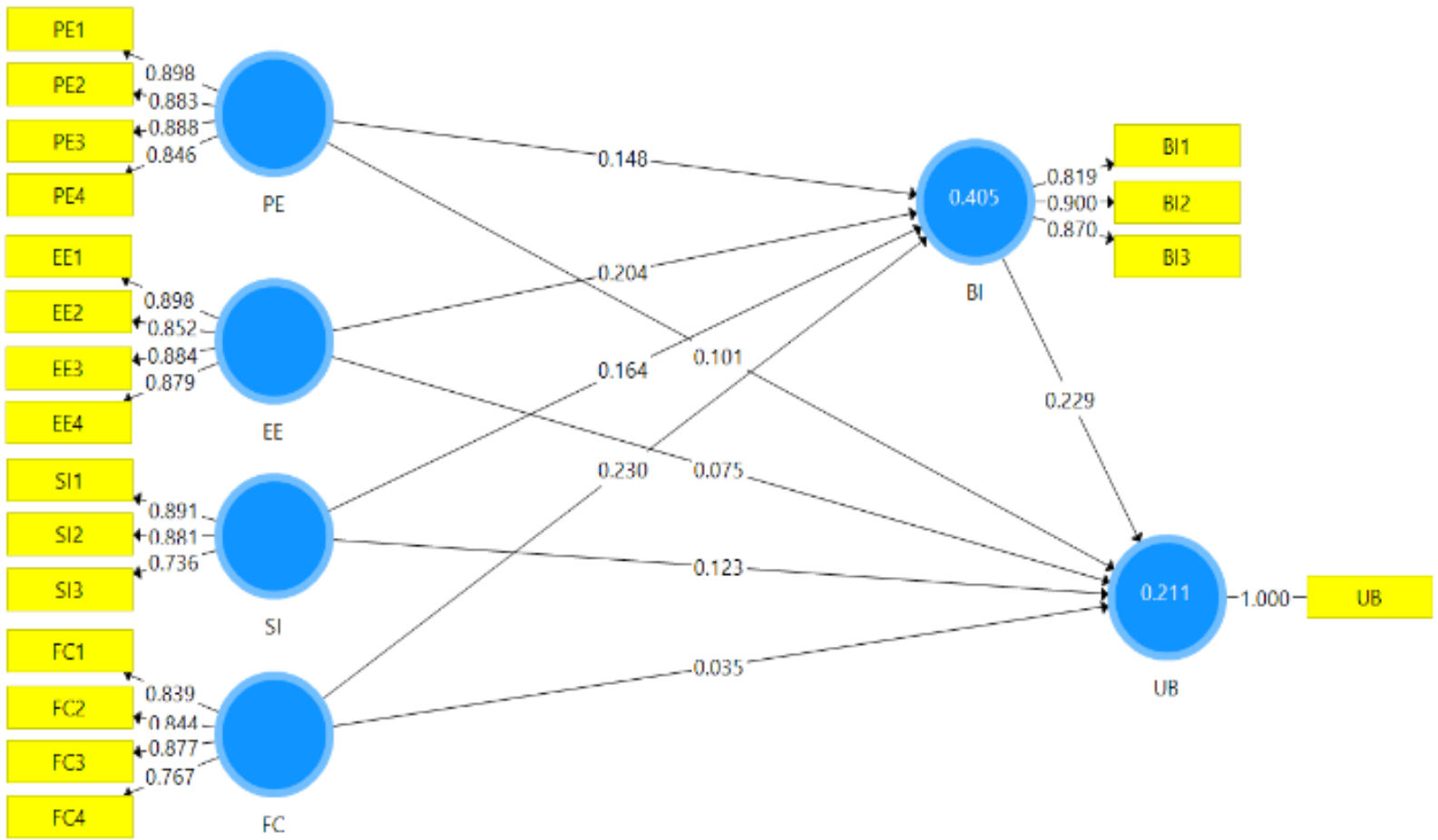

Figure 2 Measurement Model

Figure 2 presents the outcome of the measurement model. Composite reliability (CR) and coefficient alpha (CA) are above 0.70 in all internal consistency criteria (minimum CR is above 0.80 and minimum CA is above 0.70 ), suggesting internal consistency scales.

Table 1. Summary of construct reliability and validity

\begin{tabular}{ccccc}
\hline Variables & $\begin{array}{c}\text { Cronbach's } \\
\text { Alpha }\end{array}$ & rho_A & $\begin{array}{c}\text { Average } \\
\text { Composite } \\
\text { Reliability }\end{array}$ & $\begin{array}{c}\text { Variance } \\
\text { Extracted } \\
\text { (AVE) }\end{array}$ \\
\hline BI & 0.829 & 0.833 & 0.898 & 0.746 \\
EE & 0.902 & 0.907 & 0.931 & 0.772 \\
FC & 0.852 & 0.856 & 0.900 & 0.693 \\
PE & 0.902 & 0.908 & 0.931 & 0.773 \\
SI & 0.786 & 0.802 & 0.876 & 0.703 \\
UB & 1.000 & 1.000 & 1.000 & 1.000 \\
\hline
\end{tabular}

In order to assess the convergent validity, average variance extract (AVE) was used. AVE should be greater than 0.5 , suggesting that, on average, more than half of the variation of its measures is clarified by the build or latent variables[19]. As seen in Table 1, these conditions are fulfilled by all structures, with AVE values greater than the prescribed values.

Table 2. Summary of Discriminant validity

\begin{tabular}{lllllll}
\hline & BI & EE & FC & PE & SI & UB \\
\hline BI & $\mathbf{0 . 8 6 4}$ & & & & & \\
EE & 0.556 & $\mathbf{0 . 8 7 8}$ & & & & \\
FC & 0.576 & 0.701 & $\mathbf{0 . 8 3 3}$ & & & \\
PE & 0.526 & 0.736 & 0.619 & $\mathbf{0 . 8 7 9}$ & & \\
SI & 0.499 & 0.501 & 0.680 & 0.523 & $\mathbf{0 . 8 3 9}$ & \\
UB & 0.404 & 0.362 & 0.364 & 0.361 & 0.351 & $\mathbf{1 . 0 0 0}$ \\
\hline
\end{tabular}

Discriminant validity is the degree to which, by scientific criteria, a concept is very distinct from other constructs[19]. It means a construct is special and captures phenomena in the model that are not described by other constructs. Based on cross loading, discriminant validity was tested. In particular, the outward loading of an indicator on the construct should be greater than any of its cross-loading on the other construct. Table 2 reveals that each construct's outer load (in bold) is higher than the other construct's correlation. Discriminant validity is the degree to which a notion is very distinct from other constructs by empirical criteria[19]. It implies that a construct is unique and captures phenomena not represented by other constructs in the model. Discriminant validity was tested based on cross loading.

The measurement model shows that the model has excellent internal accuracy, convergent validity and validity of discriminants. Therefore, the build can be used to evaluate the structural model in this research model.

\subsection{Structural Model}

The structural model was tested between the construct using $\mathrm{R}$ square $\left(\mathrm{R}^{2}\right)$ and path significance stages. The outcome of the $\mathrm{R}^{2}$ test is shown in table 3 .

Table 3. R Square and R Square Adjusted

\begin{tabular}{lcc}
\hline & R Square & R Square Adjusted \\
\hline BI & 0,405 & 0,393 \\
UB & 0,211 & 0,191 \\
\hline
\end{tabular}

Overall, 40.5 percent (R2) of variation in behavioral intention was clarified by the principle of performance expectation, effort expectation, social influence and facilitating condition. Then, behavioral purpose clarified the 21.1 percent variation in use behavior.

In explaining behavioral intention (BI), effort expectancy (EE), social influence (SI) and facilitating condition (FC) are statistically significant findings. This contradicts the $\mathrm{H} 3, \mathrm{H} 5$, and $\mathrm{H} 7$ hypotheses. In describing 
behavioral intention, performance expectancy (PE) is not statistically significant. H1 is therefore not confirmed.

Table 4. Summary of Hypotheses Testing

\begin{tabular}{lccc}
\hline Relationships & Beta & T Statistics & P Values \\
\hline BI -> UB & 0.229 & 2.466 & $0.014^{*}$ \\
EE -> BI & 0.204 & 2.111 & $0.035^{*}$ \\
EE -> UB & 0.075 & 0.598 & 0.550 \\
FC -> BI & 0.230 & 2.242 & $0.025^{*}$ \\
FC -> UB & 0.035 & 0.314 & 0.754 \\
PE -> BI & 0.148 & 1.272 & 0.203 \\
PE -> UB & 0.101 & 1.112 & 0.266 \\
SI -> BI & 0.164 & 2.159 & $0.031^{*}$ \\
SI -> UB & 0.123 & 1.334 & 0.182 \\
\hline
\end{tabular}

*significant at 0.05 level

The research presumed that PE, EE, SI and FC could justify the usage of behavior (UB). The findings, however, indicate that none of these considerations are statistically significant. H2, H4, H6, H8 are not, however, confirmed. The most important finding, describe the use behaviour of e-money is behavioral intention. H9 is, thus, confirmed. Overall, 4 are verified by the evidence among the 9 theories formulated.

\section{DISCUSSION}

$40.5 \%$ of the behavioral intention (BI) variance is identified in the research model. The results of this study indicate that performance expectancy has no influence on the behavioural intention and use behaviour of e-money. This was in contrast to the results mentioned earlier [9, $11,12,14,15,16,17,20,21,22]$. Performance expectation was not regarded by the respondent as one of the most relevant precedents of e-money behavioral intention and usage. The outcome of this study is in line with the previous study by Rahmiati et al.[3].

The most important factor affecting BI is effort expectancy. The earlier reports $[11,15,23,24,25,26]$ support the outcome of this study. The finding implies that the more e-money is viewed by the consumer as easy to access, understand and study, the more e-money is expected to be used. This compares, however, with Oliveira et al.[17] and Sumak \& Sorgo[16].

Social influence on behavioral intent was shown by external control. This is because the more powerful individuals (such as family and friends) believe that using e-money is a smart thing, the more e-money is used by consumers. In addition, in culture, the use of emoney is still seen as a status symbol. This observation is confirmed in earlier studies $[10,11,15]$, but contrary to $[17,20]$.

The outcome also showed that behavioural intention is favorably influenced by facilitating the condition. In order to help them use e-money technology, e-money users assume that tools, expertise and compatible emoney technology are available. This observation was followed by earlier studies[12,17] and compared with Isaac et al.[11]. Facilitating conditions, on the other hand, have been shown to have no major impact on use behaviour. This is consistent with what was stated in earlier research by Baptista \& Oliveira[21].
The most important structure to describe the use behavior of e-money is behavioral intent. Using e-money activity increases 0.22 standardized unit, ceteris paribus, if behavioral intention increases one standardized unit. The model, however, describes approximately 21.1 per cent of the variance in e-money use behavior.

\section{CONCLUSION}

This research offered good evidence for UTAUT's assessment of e-money usage behaviour. Since the researchers expanded the UTAUT model and examined the effect of system use on the individual effect, the results noted in this study could contribute to the existing literature as specially in management information system. The findings of the analysis revealed that effort expectation, social influence and facilitating condition were strong determinants of behavioural intention. There is no clear influence of performance expectancy, effort expectancy, social impact on use behaviour. Finally, behavioural intention is a deciding factor in e-money use behaviour.

\section{REFERENCES}

[1] Susanto, P., Hoque, M. E., Hashim, N. M. H. N., Shah, N. U., \& Alam, M. N. A. (2020). Moderating effects of perceived risk on the determinantsoutcome nexus of e-money behaviour. International Journal of Emerging Markets.

[2] Sistem Pembayaran Masih menjadi Kendala Ecommerce. Online available from https://www.pikiran-rakyat.com/ekonomi/pr01306628/sistem-pembayaran-masih-menjadikendala-e-commerce.

[3] Rahmiati., Engriani, Y \& Putri, R. R. E. The Influence of Trust, Perceived Usefulness, and Perceived Ease of Using Intensity of E-Money with Attitude Toward Using Intervening Variable in Padang City. Advances in Economics, Business and Management Research, Vol. 97, 696-701, 2019.

[4] Khatimah, H., Susanto, P \& Abdullah, N. L. Hedonic Motivation and Social Influence on Behavioral Intention of E-Money: The Role of Payment Habit as a Mediator. International Journal of Entrepreneurship, Vol. 23, No. 1, 2019.

[5] Deny. Faktor-Faktor yang Mempengaruhi Adopsi Aplikasi Go-Pay Menggunakan UTAUT2. ULTIMA InfoSys, Vol. X, No. 1, 19-26, 2019.

[6] Susanto P., Abdullah, N.L., Rela, I. Z \& Wardi Y. Understanding Emoney adoption: Extending the unified theory of acceptance and use of technology (UTAUT). International Journal of Applied Business and Economic Research, Vol. 15, No. 18, 335-345, 2017.

[7] Miliani, Lani., Purwanegara, Mustika Sufiati., \& Indriani, Mia Tantri Diah. Adoption Behavior of EMoney Usage. Information Management and Business Review, 5(7): 369-379, 2013.

[8] Anjelina. Persepsi Konsumen Pada Penggunaan EMoney. Journal of Applied Managerial Accounting, 2(2): 219-231, 2018. 
[9] Venkatesh, V., Morris, M. G., Davis, G. B., \& Davis, F. D. User Acceptance of Information Technology: Toward a Unified View. MIS Quarterly, Vol. 27, No. 3, 425-478, 2003.

[10] Handayani, T \& Sudiyana. Analisis Penerapan Model UTAUT (Unified Theory of Acceptance and Use of Technology) Terhadap Perilaku Pengguna Sistem Informasi (Studi Kasus: Sistem Informasi Akademik Pada STTNAS Yogyakarta). Jurnal Angkasa, Vol. 7, No. 2, 2015.

[11] Isaac, Osama., Abdullah, Zaini., Aldholay, Adnan H., \& Ameen, Ali Abdulbaqi. Antecedents and Outcomes of Internet Usage Within Organization in Yemen: An Extension of the Unified Theory of Acceptance and Use of Technology (UTAUT) Model. Asia Pasific Management Review, 24, 335$354,2019$.

[12] Gunawan, Hendro., Sinaga, Benyamin Langgu \& WP, Sigit Purnomo. Assessment of the Readiness of Micro, Small and Medium Enterprise in Using E-Money Using the Unified Theory of Acceptance and Use Tehnology (UTAUT) Method. Procedia Computer Science, 161 (2019), 316- 323.

[13] Davis, Fred D., Bagozzi, Richard P., \& Warshaw Paul R. User Acceptance of Computer Technology: A Comparison of Two Theoretical Models. Management Science, Vol. 35, No. 8, 982-1003, 1989.

[14] Venkatesh, Viswanath., Thong, James Y.L \& Xu, Xin. Consumer Acceptance and Use of Information Technology: Extending the Unified Theory of Acceptance and Use of Technology. MIS Quarterly, Vol. 36, No. 1, 157-178, 2012.

[15] Abrahao, Ricardo de Sena., Moriguchi, Stella Naomi., \& Andrade, Darly Fernando. Intention of Adoption of Mobile Payment: An Analysis in the Light of the Unified Theory of Acceptance and Use of Technology (UTAUT). RAI Revista de Administracao e Inovacao, Vol. 13, No. 1, 221-230, 2016.

[16] Sumak, Bostjan \& Sorgo, Andrej. The Acceptance and Use of Interactive Whiteboards Among Teachers: Differences in UTAUT Determinants Between Pre- and Post-Adopters. Computer in Human Behavior, 64, 602-620, 2016.

[17] Oliveira, T., Fariaa, M., Abraham, M. T. B., \& Popovic, Ales. Extending the Understanding of Mobile Banking Adoption: When UTAUT Meets TTF and ITM. International Journal of Information Management, Vol. 34, No. 5, 689-703, 2014.

[18] Hair, Joseph E., Anderson, Rolph E., Tatham, Ronald L \& Black, William C. Multivariate Data
Analysis, Prentice Hall, Upper Saddle River, New Jersey, 2006.

[19] Hair, Joseph E., Hult, G. Tomas M., Ringle, Christian M \& Sarstedt, Marko. A Primer on Partial Least Squares Structural Equation Modeling (PLS_SEM), Second Edition, Sage Publication, Inc, 2017.

[20] Chauhan, S \& Jaiswal, M. Determinants of Acceptance of ERP Software Training in Business school: Empirical Investigation Using UTAUT Model. The International Journal of Management Education, Vol. 14, 248-262, 2016.

[21] Baptista, Goncalo \& Oliveira, Tiago. Understanding Mobile Banking: The Unified Theory of Acceptance and Use of Technology Combined with Cultural Moderators. Computer in Human Behavior, Vol. 50, 418-430, 2015.

[22] Luo, Xin., Li, Han., Zhang, Jie \& Shim, J. P. Examining Multi-Dimensional Trust and MultiFaceted Risk in Initial Acceptance of Emerging Technologies: An Empirical Study of Mobile Banking Services. Decision Support System, Vol. 49 No. 2, 222-234, 2010

[23] Prasetyo, D. Y. Penerapan Metode UTAUT (Unified Theory of Acceptancec and Use of Technology) dalam Memahami Penerimaan dan Penggunaan Website KKN LPPM UNISI. Jurnal Sistemasi, Vo. 6, No. 2, 26-34, 2017.

[24] Martin, C., Oliveira, T \& Popovic, A. Understanding the Internet Banking Adoption: A Unified Theory of Acceptance and Use of Technology and Perceived Risk Application. International Journal of Information System, Vol 34, No. 1, 1-13, 2014.

[25] Chao, Chen-Min. Factors Determining the Behavioral Intention to Use Mobile Learning: An Application and Extension of the UTAUT Model. Frontier in Psychology, 2019.

[26] Rahmiati \& Yuannita, I.I. The Influence of Trust, Perceived Usefulness, Perceived Ease of Use, and Attitude on Purchase Intention. Jurnal Kajian manajemen Bisnis, Vol. 8, No. 1, 27-34, 2019. 